\title{
Decision Support System for Determining the Best Hospital Nurses Grandmed Method Using Simple Additive Weighting (SAW)
}

\author{
Ester Simanjuntak $^{1}$, Bosker Sinaga ${ }^{2}$ \\ ${ }^{1,2}$ Informatics Engineering Study Program, STMIK Pelita Nusantara JL. St. Iskandar Muda \\ No. 1 Medan, Nort Sumatera, Indonesia 20154 \\ E-mail: esterborjun1596@gmail.com
}

\begin{abstract}
Decision support system is a combination of sources of individual intelligence with the ability of components to improve the quality of decisions. Also decision support systems are computer-based information systems for management decision-making that deal with semi-structural problems. The purpose of this study is to the make the application of nurse employees in Grandmed Hospital Based on the results of research that has been Discussed items, namely the Decision Support System for Determining the Best Nurses in Grandmed Hospital by Using the Simple Additive Wieghting (SAW) Method with the benefit of being Able to Facilitate the processing of the data and Facilitate nurse in Determination of the best nurse for a promotion to a nurse at Grandmed Hospital.
\end{abstract}

Keywords: Decision Support System, The Best Nurse, Simple Addite Weighting (SAW).

\section{Introduction}

Decision Support System (DSS) is a model-based system that consists of procedures for processing the data and considerations to assist in making decisions. In order to successfully achieve its objectives, the system must be simple and easy to control. It is important that this system should be based computers and is used in addition to the ability of a person's problem solving. CMS aims to provide information, to guide, to give predictions as well as directing the user information in order to make better decisions. The nurse as one of the important assets in the administration of health facilities, in addition to sabagai paramedics to care for patients, nurses are most often related directly and automatically always actively communicate with patients. There are some problems in the can by the HR related to the determination of the best nurses as nursing services are less than satisfactory, less kindly attitude of nurses in providing information, lack of initiative to help the patient. In essence the conditions above shows that not all nurses are able to optimize aspects as indicators of the performance. Complaints inpatient nursing care shown to the patient's dissatisfaction with the services of nurses in the work. Generally have fasktor considerations or factors before taking a decision as an example of skill, discipline, leadership and teamwork. That requires a system that can help the team terkomputerasasi nurse service. To resolve the above problems concerning the determination of the best nurses in the health service with international standard quality. Based on the above background, the authors determine a title of the study entitled "Decision Support System for Determining the Best Nurse at Hospital Grandmed Method Using Simple Additive Weighting (SAW)".According to Fishburn and MacCrimmon in (Munthe, 2013) suggests that the method of Simple Additive Weight (SAW), often also referred to as the weighted summation method. The basic concept of the method Simple Additive Weight (SAW) is looking for a weighted summation of the rating performance of each alternative on all attributes. According to (Asnawati and Kanedi, 2012) "The assessment criteria can be determined according to the needs of the company."

\section{Theory}

a. The system is a network of procedures that are interconnected, gathered together to perform activities or to perform a specific target. The systems approach which is a network of more procedures emphasize sequences in the system operation.

b. The decision is an activity choose a strategy or action in solving the problem. The act of choosing a strategy or action which assure the best solution for something that the decision-making.

c. Nurses are an intergral part of the health service that provides services to individuals, families, groups and communities both healthy atapun comprehensively pain includes physical, psychological and spiritual with nursing tips so it impact on healing and patient satisfaction. The nursing actions embodied in a process of nursing care that includes assessment, diagnosing ,, the planning, implementation and evaluation (PPNI, 2010). 
d. SAW method has been known as a weighted summation method. Elementary concepts SAW method is finding a weighted summation of rating performance on each alternative on all attributes. SAW method can help in the decision of a case, but calculations using this SAW only produces the greatest value will be chosen as the best alternative. The calculation will be in accordance with this method if alternative Tepilih meet predetermined criteria. SAW method is more efficient because of the time required in a shorter calculation. SAW method requires a process of normalizing the decision matrix $(\mathrm{X})$ to a certain scale that can be compared with all the ratings of existing alternatives.

The completion of the steps in using it are:

1) Specifies an alternative, namely Ai.

2) Specify the criteria that will be used as reference in decision-making, ie $\mathrm{Cj}$.

3) Providing compatibility rating value of each alternative on each criterion.

4) Determining the weight of preference or importance level (W) of each criterion.

$\mathrm{W}=[\mathrm{W} 1, \mathrm{~W} 2, \mathrm{~W} 3, \ldots, \mathrm{WJ}]$.

5) Creating a table rating the suitability of each alternative on each criterion for each criterion.

6) Make a decision matrix $(X)$ which is formed from a table rating the suitability of each alternative on each criterion. $X$ value of each alternative $(\mathrm{Ai})$ on each criterion $(\mathrm{Cj})$ is already determined, wherein, $\mathrm{i}=1,2, \ldots$ $\mathrm{m}$ and $\mathrm{j}=1,2, \ldots \mathrm{n} \cdot V_{i}={ }_{j=1}^{n} W_{j} r_{i j}$

7) Normalized decision matrix by calculating the value of ternomalisasi performance rating (rij) of the alternative Ai on criteria $\mathrm{Cj}$.

Where :

$\mathrm{Ri} \mathrm{j}=$ value normalized performance rating

$\mathrm{Xi}=$ the value of the attributes of each criterion

Max $x i j=$ largest value of each criterion $\mathrm{i}$

Min $x i j=$ smallest value of each criterion $i$

Benefit $=$ if the greatest value is the best

Cost $=$ if the smallest value is best

Where rij is the normalized performance rating of alternatives on attribute $\mathrm{Ai} \mathrm{Cj} ; \mathrm{i}=1,2, \ldots, \mathrm{m}$ and $\mathrm{j}=$ $1,2, \ldots, n$.

8) The results of the rating value kinerj ternomalisasi (rij) form a normalized matrix (R). $r_{i j}=\frac{x_{i j}}{\operatorname{Maxx}_{i j}}$

9) The final result of the preference value (Vi) obtained from the sum of the normalized rows of the matrix multiplication element $(\mathrm{R})$ with a preference weighting $(\mathrm{W})$ corresponding eleman column matrix (W). $V_{i}={ }_{j=1}^{n} W_{j} r_{i j}$

Where :

$V i=$ Ranking for each alternative

$w j=$ Value of the weight of each criterion $\mathrm{rij}=$ value normalized performance rating Vi larger value indicates that the alternative $\mathrm{Ai}$ is elected,

\section{Data analysis}

The data analysis will explain the data will be used in decision support systems to be ready for the data used in the calculations. The data used in decision support system is derived from the value Grandmed Hospital nurse's competence comes from the assessment conducted by the relevant desivi directly in the field. In addition, the data collected is also done through the library to study ffor the appropriate data, then in order to get a conclusion Oalah sesiai to the research conducted.

Table 1.

\section{Criteria}

\begin{tabular}{llll}
\hline Criteria & Information & attribute & Weight \\
\hline C1 & Skills & Benefit & 20 \\
C2 & Discipline & Benefit & 20 \\
C3 & Leadership & Benefit & 40 \\
C4 & Cooperation & cost & 20 \\
\hline
\end{tabular}

a. Weight

In each of these criteria will be determined weights to each criterion has a different amount. Below is a table of weights to each criterion. 
Journal of Computer Networks, Architecture and High Performance Computing e-ISSN 2655-9102, Volume 2, No. 1, January 2020, pp 45-52

Table 2.

weights Criteria

\begin{tabular}{llll}
\hline Criteria & \multicolumn{1}{c}{ Information } & \multicolumn{1}{c}{ Himpunankriteria } & Weight \\
\hline C1 & Skills & $(86-100)$ SangatBaik & 40 \\
& & $(76-85)$ Good & 30 \\
& & $(66-75)$ Enough & 15 \\
& $(51-65)$ Less & 10 \\
& & $(0-50)$ SangatKurang & 5 \\
C2 & Discipline & $(86-100)$ SangatBaik & 40 \\
& & $(76-85)$ Good & 30 \\
& & $(66-75)$ Enough & 15 \\
& & $(51-65)$ Less & 10 \\
C3 & $(0-50)$ SangatKurang & 5 \\
& & $(86-100)$ SangatBaik & 40 \\
& & $(76-85)$ Good & 30 \\
& & $(66-75)$ Enough & 15 \\
& & $(51-65)$ Less & 10 \\
& & $(0-50)$ SangatKurang & 5 \\
& & $(86-100)$ SangatBaik & 40 \\
& & $(76-85)$ Good & 30 \\
& & $(66-75)$ Enough & 15 \\
& & $(51-65)$ Less & 10 \\
& & $(0-50)$ SangatKurang & 5 \\
\hline
\end{tabular}

b. Sample case

Of the nurses at the Hospital Grandmed, only five people were taken as an example for the application of the Simple Additive weighting method (SAW) in the determination of the best nurses. The value of each nurse can be seen in the following table:

Table 3.

Data nurse

\begin{tabular}{clcccc}
\hline \multirow{2}{*}{ NIK } & \multicolumn{1}{c}{ Name } & \multicolumn{3}{c}{ Score } \\
\cline { 3 - 6 } & & $\begin{array}{c}\text { Responsible } \\
\text { (C1) }\end{array}$ & $\begin{array}{c}\text { Cooperation } \\
\text { (C2) }\end{array}$ & $\begin{array}{c}\text { Intelligence } \\
\text { (C3) }\end{array}$ & $\begin{array}{c}\text { Absent } \\
\text { (C4) }\end{array}$ \\
\hline 2351 & Risma Kartika Sari, S.Kep & Enough & Enough & 75 & Enough \\
400 & Nurzaini, Amk,S.Kep,Ns & Enough & Enough & 80 & Enough \\
1945 & Evy pionika, Skep, Ns & Very good & Well & 90 & Very good \\
1194 & Anni kholila, Amk,S.Kep.Ns. & Enough & Well & 85 & Enough \\
2162 & Sartika dewi asnita sihombing, S.Kep, Ns & Enough & Enough & 81 & Enough \\
\hline
\end{tabular}

Table 4.

Values Skills

\begin{tabular}{ll}
\hline \multicolumn{1}{c}{ Name Nurse } & \multicolumn{1}{c}{ Value (C1) } \\
\hline Risma Kartika Sari, S.Kep & $\mathrm{C} 1=$ Enough \\
Nurzaini, Amk,S.Kep,Ns & $\mathrm{C} 1=$ Enough \\
Evy pionika, Skep, Ns & $\mathrm{C} 1=$ Very Good \\
Anni kholila, Amk,S.Kep.Ns. & $\mathrm{C} 1=$ Enough \\
Sartika dewi asnita sihombing, S.Kep, Ns & $\mathrm{C} 1=$ Enough \\
\hline
\end{tabular}


Table 5

Value Disciplines

\begin{tabular}{ll}
\hline \multicolumn{1}{c}{ Name Nurse } & Value (C2) \\
\hline Risma Kartika Sari, S.Kep & C2 $=$ Enough \\
Nurzaini, Amk,S.Kep,Ns & C2 $=$ Enough \\
Evy pionika, Skep, Ns & C2 $=$ Good \\
Anni kholila, Amk,S.Kep.Ns. & C2 $=$ Good \\
Sartika dewi asnita sihombing, S.Kep, Ns & C2 $=$ Enough \\
\hline
\end{tabular}

Table 6

Value Leadership

\begin{tabular}{lll}
\hline \multicolumn{1}{c}{ Name Nurse } & Value (C3) & \multicolumn{1}{c}{ The set of criteria } \\
Risma Kartika Sari, S.Kep & $\mathrm{C} 3=75$ & Enough \\
Nurzaini, Amk,S.Kep,Ns & $\mathrm{C} 3=80$ & Well \\
Evy pionika, Skep, Ns & $\mathrm{C} 3=90$ & Very good \\
Anni kholila, Amk,S.Kep.Ns. & $\mathrm{C} 3=85$ & Well \\
Sartika dewi asnita sihombing, S.Kep, Ns & $\mathrm{C} 3=81$ & Well \\
\hline
\end{tabular}

Table 7.

Values Cooperation

\begin{tabular}{ll}
\hline \multicolumn{1}{c}{ Name Nurse } & \multicolumn{1}{c}{ Value (C4) } \\
\hline Risma Kartika Sari, S.Kep & $\mathrm{C} 4=$ Enough \\
Nurzaini, Amk,S.Kep,Ns & $\mathrm{C} 4=$ Enough \\
Evy pionika, Skep, Ns & $\mathrm{C} 4=$ Very Good \\
Anni kholila, Amk,S.Kep.Ns. & $\mathrm{C} 4=$ Enough \\
Sartika dewi asnita sihombing, S.Kep, Ns & $\mathrm{C} 4=$ Enough \\
\hline
\end{tabular}

Table 8

Match Rating of Any Alternatives

\begin{tabular}{lcccc}
\hline \multicolumn{1}{c}{ Alternative } & \multicolumn{4}{c}{ Criteria } \\
& C1 & C2 & C3 & C4 \\
\hline Risma Kartika Sari, S.Kep & 15 & 15 & 15 & 15 \\
Nurzaini, Amk,S.Kep,Ns & 15 & 15 & 30 & 15 \\
Evy pionika, Skep, Ns & 40 & 30 & 40 & 40 \\
Anni kholila, Amk,S.Kep.Ns. & 15 & 30 & 30 & 15 \\
Sartika dewi asnita sihombing, S.Kep, Ns & 15 & 15 & 30 & 15 \\
\hline
\end{tabular}

c. Calculating the value of the normalization of each alternative by the formula:

Information:

$$
r_{i j}=\frac{x_{i j}}{\operatorname{Maxx}_{i j}}
$$

$$
\begin{array}{ll}
\mathrm{Rij} & =\text { Normalization performance rating value } \\
\mathrm{Xij} & =\text { attribute value that is owned from each criterion } \\
\mathrm{Max} \mathrm{Xij} & =\text { the greatest value of each criterion } \\
\text { Benefit } & =\text { the greatest value is the best }
\end{array}
$$

Normaliasisi to the criteria can be seen as follows.

1) For responsibility criteria (C1) ??? 


$$
\begin{aligned}
& r 11 \frac{2}{\operatorname{Max}\{2,3,5,4,4\}}=\frac{2}{5}=0.4 \\
& r 21 \frac{3}{\operatorname{Max}\{2,3,5,4,4\}}=\frac{3}{5}=0.6 \\
& r 31 \frac{5}{\operatorname{Max} 2,3,5,4,4}=\frac{5}{5}=1 \\
& r 41 \frac{4}{\operatorname{Max}\{2,3,5,4,4\}}=\frac{4}{5}=0,8 \\
& r 51 \frac{4}{\operatorname{Max}\{2,3,5,4,4\}}=\frac{4}{5}=0,8
\end{aligned}
$$

2) For the same work criteria (C2) ???

$$
\begin{aligned}
& r 12 \frac{4}{\operatorname{Max}\{4,4,3,2,1\}}=\frac{4}{4}=1 \\
& r 22 \frac{4}{\operatorname{Max}\{4,4,3,2,1\}}=\frac{4}{4}=1 \\
& r 32 \frac{4}{\operatorname{Max}\{4,4,3,2,1\}}=\frac{4}{4}=1 \\
& r 42 \frac{2}{\operatorname{Max}\{4,4,3,2,1\}}=\frac{2}{4}=0,5 \\
& r 52 \frac{1}{\operatorname{Max}\{4,4,3,2,1\}}=\frac{1}{4}=0,25
\end{aligned}
$$

C. To wit criteria (C3)

$$
\begin{aligned}
& r 13 \frac{4}{\operatorname{Max}\{4,5,3,2,1\}}=\frac{4}{5}=0,8 \\
& r 23 \frac{5}{\operatorname{Max}\{4,5,3,2,1\}}=\frac{5}{5}=1 \\
& r 33 \frac{5}{\operatorname{Max}\{4,5,5,2,1\}}=\frac{5}{5}=1 \\
& r 43 \frac{2}{\operatorname{Max}\{4,5,3,2,1\}}=\frac{2}{5}=0,4 \\
& r 53 \frac{1}{\operatorname{Max}\{4,5,3,2,1\}}=\frac{1}{5}=0,2
\end{aligned}
$$

d. For Absent criteria (C4) ???

$$
\begin{aligned}
& r 14 \frac{1}{\operatorname{Max}\{1,4,2,4,3\}}=\frac{1}{4}=0,25 \\
& r 24 \frac{4}{\operatorname{Max} 1,4,2,4,3}=\frac{4}{4}=1 \\
& r 34 \frac{4}{\operatorname{Max}\{1,4,4,4,3\}}=\frac{4}{4}=1 \\
& r 44 \frac{4}{\operatorname{Max} 1,4,2,4,3}=\frac{4}{4}=1 \\
& r 54 \frac{3}{\operatorname{Max}\{1,4,2,4,3\}}=\frac{3}{4}=075
\end{aligned}
$$

The result of normalization is made in the form of a matrix of normalization as below this:

$$
\left\{\begin{array}{clcc}
0.4 & 1 & 0.8 & 0.25 \\
0.6 & 1 & 1 & 1 \\
1 & 1 & 1 & 1 \\
0.8 & 0.5 & 0.4 & 1 \\
0.8 & 0.25 & 0.2 & 0.75
\end{array}\right\}
$$


This table describes the value calculation of final results SAW method of normalization sum of the weights to each criterion.

Table 9

Eligibility Value Method SAW

\begin{tabular}{lll}
\hline No. & \multicolumn{1}{c}{ Score } & \multicolumn{1}{c}{ Category } \\
\hline 1 & $85-100$ & worthy \\
2 & $0-84$ & Not feasible \\
\hline
\end{tabular}

ranking

And made into a matrix multiplication $\mathrm{W} * \mathrm{R}$ and summing the results of multiplication untukmemperoleh best alternative to melakukanperangkingan the greatest value as follows:

$\mathrm{W}=0.35$

0.25

0.25

$$
V_{i}=W_{j=1}^{n} r_{i j}
$$

Preference value to determine the results of ranking is as follows:

$V_{1}=(0.35 \times 0.4)+(0.25 \times 1)+(0.25 \times 0.8)+$ on $(0.15 \times 0.25)=0.59$

$V_{2}=(0.35 \times 0.6)+(0.25 \times 1)+(0.25 \times 1)+(0: 15 \times 1)=0.86$

$V_{3}=(0.35 \times 1)+(0.25 \times 1)+(0.25 \times 1)+(0: 15 \times 1)=1$

$V_{4}=(0.35 \times 0.8)+(0.25 \times 0.5)+(0.25 \times 0.4)+(0.15 \times 1)=0.665$

$(0.35 \times 0.8)+(0.25 \times 0.25)+(0.25 \times 0.2)+$ on $(0.15 \times 0.75)=0.505$

From the results of the matrix multiplication $\mathrm{W} * \mathrm{R}$ is obtained, then the decision values obtained final results are as follows:

table 10

Value Results on Ranking

\begin{tabular}{lll}
\hline \multicolumn{2}{c}{ Value Results on Ranking } \\
& Results on Ranking & Feasibility Kategiori \\
\hline Risma Kartika Sari, S.Kep & 0.59 & Not feasible \\
Nurzaini, Amk,S.Kep,Ns & 0.86 & Not feasible \\
Evy pionika, Skep, Ns & 1 & worthy \\
Anni kholila, Amk,S.Kep.Ns. & 0.665 & Not feasible \\
Sartika dewi asnita sihombing, S.Kep, Ns & 0.505 & Not feasible \\
\hline
\end{tabular}

\section{d. Design}

a) Use Case Diagram

Designing usecase used to see graphically how the user interaction with the system dibagun, as below: 


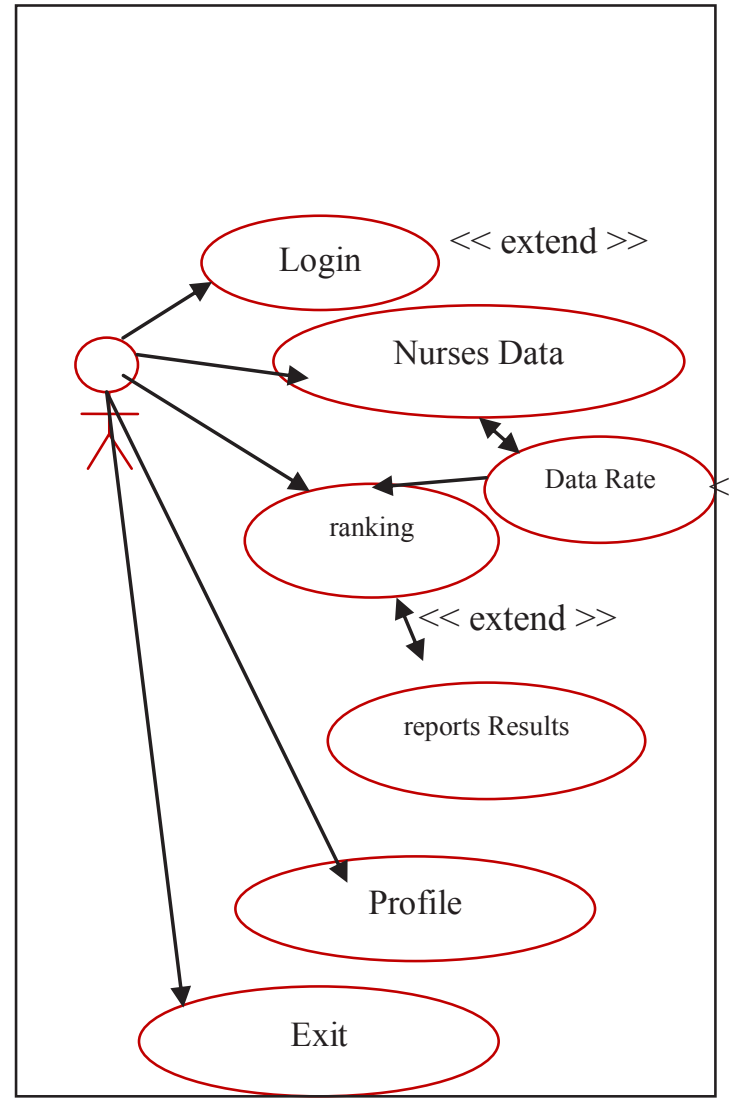

Picture 1. Use Case Diagram

\section{Conclusion}

Based on the research results from the Decision Support System Determining the Best Hospital Nurses Grandmed Using Simple Additive weighting method (SAW), it can be concluded as follows:

1. Simple Additive weighting method (SAW) is able to support recruitment decisions by providing alternative perangkingan.

2. Facilitate management of employee data for the determination of the best nurses in grandmed hospitals.

3. With this application a better view and structured in the process of data input and penilainan every nurse.

\section{Reference}

[1] Edi Ismanto dan Noverta Effendi, “Sistem Pendukung Keputusan Penerimaan Karyawan Dengan Metode Simple Additive Weighting (SAW)", SATIN - Sains dan Teknologi Informatika, 2017, 3(1), 2-3.

[2] Yusuf Wahyudi, Suwarni, Andayani, "Sistem Pendukung Keputusan Pengangkatan Pegawai Negeri Sipil, Dalam Jabatan Struktural Pada Badan Kepegawaian daerah provinsi bengkulu" Jurnal Media Infotama, 2013, 9(1), 192-192.

[3] Abdul Rozag, Raden Kelik Hardinto, Annurrahman, Dewi Susanti, "Sistem Informasi Pembayaran Tambahan Penghasilan Berdasarkan Beban Kerja Pada Dinas Pendidikan Dan Kebudayaan Kabupaten Tanah Bumbu" Jurnal Sistem dan Teknologi Informasi, 2018, 4(1), 45.

[4] Fanny Andalia, Eko Budi Setiawan, " Pengembangan Sistem Informasi Pengolahan Data Pencari Kerja Pada Dinas Sosial Dan Tenaga Kerja Kota Padang" Jurnal Ilmiah Komputer dan Informatika, 2015, 4(2), 93-94.

[5] Sri Wahyuni, Niken Wahyu Ning Tiyas, "Rancang Bangun Sistem Pendukung Keputusan Pemberian Penghargaan Karyawan Dengan Metode AHP Pada PT Bumi Cikarang Steel Industries" Jurnal Informatika SIMANTIK, 2017, 2(2), 32.

[6] Frieyadie, "Penerapan Metode Simple Additive Weighting (SAW) Dalam Sistem Pendukung Keputusan Promosi Kenaikan Jabatan" Jurnal Pilar Nusa Mandiri, 2016, 12(1), 41.

[7] Arief M Rudianto. 2011. Pemrograman Web Dinamis Menggunakan PHP dan MySQL. C.V ANDI OFFSET. 
Journal of Computer Networks, Architecture and High Performance Computing e-ISSN 2655-9102, Volume 2, No. 1, January 2020, pp 45-52

Yogyakarta.

[8] Aditya, Alan Nur. 2011. Jago PHP \& MySQL Dalam Hitungan Menit. Jakarta: Dunia Komputer.

[9] Murni, M., \& Bosker, S. 2018. Sistem Pendukung Keputusan Penilaian Hasil Belajar Dengan Metode Topsis. Jl. Prof. T. Zulkarnain No.3 Medan Sumatera Utara: CV. Rudang Mayang.. 